\title{
End of Finnish Population Growth
}

\section{JARL LINDGREN}

Acting Research Director, Docent

The Population Research Institute

During the decades after World War II, social development in Finland has been characterized by a strong structural change, which in many respects has been faster than in other European countries. The proportion of the economically active population employed in agriculture declined from 46 percent in 1950 to 8 percent in 1985 . Internal migration in the 1950 s and the 1960 s was intensive. Those living in sparsely settled areas moved to the more urbanized and industrialized southern Finland. Emigration, mainly to Sweden, was also important. In 195038 percent of the population lived in urban centers, while in 1985 the figure was over 60 percent. For urban municipalities, 90 percent of the increase in population has actually been caused by migration. At the same time the economically active population employed in the service industries has increased from 26 to 57 percent.

Another characteristic feature has been the increasing participation of women in the labor force. The participation rate is high internationally: in 1970 the proportion of female labor force as a percentage of female population aged 15-74 years was already 55 percent. During the following years it grew annually and was 66 percent in 1985 (OSF 1985 XL:11): As to economic development the gross domestic product has increased rather rapidly. In 1988 it was somewhat more than 4 times greater than in 1950 or 21.266 US\$ per capita at current prices using purchasing power parities (OECD 1990, 26), i.e. practically almost at the same level as in Sweden and Norway.

At the beginning of the 1970s Finland's population development reached the phase typical for modern industrialized countries. Population growth had definitely slowed down and mortality had stabilized at a relatively low level. Only fertility appeared to be still clearly declining.

The drop in fertility and the stabilization of the mortality rates have caused a continuing increase in the proportion of the elderly and slowed down natural growth. However, in spite of the declining fertility there has been an annual excess of births over deaths, which has dropped since the end of the 1950 s from 10 per thousand to $3-4$ per thousand in the 1980 s.

\section{Towards an aging population}

During the last decades the age distribution has changed toward a growing proportion of the aged and of adults of working age, while the proportion of children has sunk somewhat. Since 1950 the number of children has decreased by 21 percent, the number of adults of working age, however, increased by 30 percent, and the number of aged by altogether 127 percent. In 198519.4 percent of the population was younger than 15 years and 12.6 percent older than 65 years, while the proportion of peo- 
Table 1. The age structure in $1900-1985$.

$\begin{array}{ccccccc}0-14 & \begin{array}{c}15-64 \\ \%\end{array} & \begin{array}{c}65- \\ \%\end{array} & \begin{array}{c}65-74 \\ \%\end{array} & \begin{array}{c}75- \\ \%\end{array} & \begin{array}{c}\text { Total amount } \\ \text { of } \\ \text { population }\end{array} \\ 1900 & 35.0 & 59.6 & 5.4 & 3.9 & 1.5 & 2655900 \\ 1920 & 33.4 & 60.7 & 5.9 & 4.2 & 1.7 & 3147600 \\ 1940 & 26.9 & 66.7 & 6.4 & 4.4 & 2.0 & 3695600 \\ 1960 & 30.1 & 62.4 & 7.4 & 5.1 & 2.3 & 4446200 \\ 1980 & 20.2 & 67.8 & 12.0 & 7.9 & 4.1 & 4787800 \\ 1987 & 19.3 & 67.7 & 12.9 & 7.5 & 5.4 & 4938600 \\ 2000 & 17.2 & 67.6 & 15.2 & 8.5 & 6.7 & 5047500 \\ 2010 & 15.8 & 67.0 & 17.2 & 9.7 & 7.5 & 5021500 \\ 2020 & 15.4 & 62.3 & 22.3 & 13.6 & 8.7 & 4903400 \\ 2030 & 14.9 & 60.4 & 24.7 & 12.7 & 12.0 & 4660800\end{array}$

Source: CSO Yearbook 1989a, 69; The Social Insurance Institution 1990.

ple of working age was 68.0 percent (Table 1). The proportion of people over 75 has increased very rapidly even if the growth numerically is small. From the beginning of the century until 1985 they have trebled.

Although mortality and, to some extent, emigration have influenced the age structure, the influence of fertility is most obvious. The irregularities of the present age structure of the Finnish population are closely connected with the changes in the number of live births during this century.

The size of the age groups born from 1910 to 1944 has varied considerably. Until 1933 there was a rather rapid decline in fertility and after that a small rise which lasted until the end of the decade. In the late 1940s the »baby-boom» age groups, were born. They are now around 40 years old and clearly seen in the current age structure (Figure 1).

The age distribution where the dependants are children below 16 years of age and the aged older than 65 is of course not feasible in our day, when schooling continues many years after children have reached the age of 16 years and a great deal of those aged 55-65 are pensioners. It would be more suitable to consider at present the age limit for young dependants to be at least 18 years and 60 for old dependants. However, the classical age distribution is most suitable in a comparison which covers the whole 20th century.

Until now the changes in the age structure have been rather small, even if the development during the last ten or fifteen years would provide a vision of the aging of the Finnish population in the future. But the great changes will occur in the next century. According to the latest population projection made by the Statistical Office (CSO Population 1989b) the Finnish population will still increase until the beginning of first decade of the next century but after that slowly decrease.

It is supposed in the projection that fertility in the coming decades will be on the same level as in the mid-1980s or in the beginning of this decade, which means that the total fertility will be stable and on the level of $1.68^{1}$. During the last few years fertility has been somewhat lower, which might imply that the future fertility in Finland is somewhat overestimated. Life expectancy for men in 2010 is projected to be 73.5 years and for women 80.7 years.

It is generally assumed that population projections of the elderly age groups are relatively reliable. The rapid decline in mortality of these age groups has, however,

1 The projection used in this study assumes that migration for the whole country decreases gradually from the present level. It has been assumed that in 1990-2010 the net migration is zero. 
made such projections less certain. According to the latest projection, in 2000 the population aged 65 years will be almost 80 percent larger than calculated in the 1969 projection. In 1980 the population aged 75 was 27 percent larger than calculated in the projection prepared in 1969.

In 2010 about 17 percent of the population will be older than 65 years (Table 1). The proportion of people older than 65 years will, however, continue to grow even after that, when the large age groups born at the end of the 1940s and in the beginning of the 1950 s have reached the age of 65 . In 2010 the proportion is calculated to be 17.2 and in 203024.7 . The proportion of children will go down to 15 percent in 2030 from 20 in 1980 . The working-age population will continue on a high level or at more than 67 percent up to 2010. After that the proportion will decline somewhat.

The greatest changes can be observed in the fast growing proportion of the aged. The great increase will take place after 2010 , when the old population will be more than twice as large as during earlier decades, with the increase from 2010 to 2020 at 27 percent. After that growth will decrease rapidly.

Figure 1. The age pyramid in 1950 and 1985.

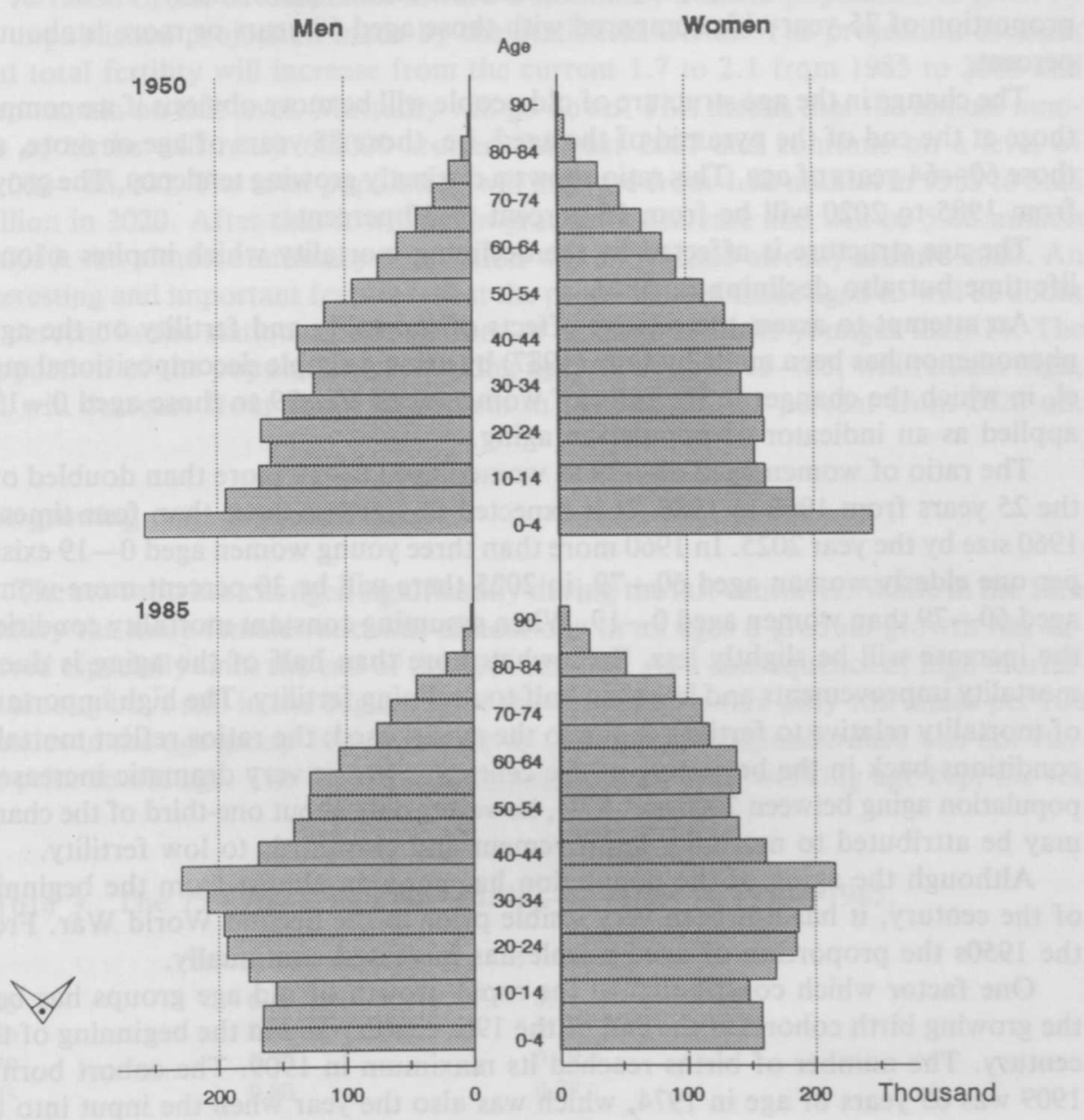

Source: OSF VI A:151, Vol 1, 1987. 
Table 2. Some age group ratios in $1985-2020$.

$\begin{array}{cccc} & 60-64 / 40-44 & 75+/ 60+ & 85+/ 60-64 \\ 1985 & 0.74 & 0.29 & 0.16 \\ 1990 & 0.58 & 0.30 & 0.20 \\ 2000 & 0.67 & 0.32 & 0.30 \\ 2010 & 1.17 & 0.29 & 0.23 \\ 2020 & 1.08 & 0.30 & 0.30\end{array}$

Source: CSO Population 1989b, No. 3; The Social Insurance Institution, 1990.

It is above all the "young» old-aged which are growing absolutely and relatively. The ratio has been rather stable during the last decades. When the large age groups reach their sixties and because continuously smaller age groups have been born since the 1960 s, the ratio between the age groups $60-64$ and $40-44$ will grow rapidly from the beginning of the next century, or from 0.67 in 2000 to 1.17 in 2010 . Occasionally the ratio will sink in the 1990 s when the large age groups pass the beginning of their forties. After 2010 it seems it will decrease again (Table 2).

The number of very old people will increase rather significantly. However, the proportion of 75 -year-olds compared with those aged 60 years or more is about 30 percent.

The change in the age structure of old people will be more obvious if we compare those at the end of the pyramid of the aged, i.e. those 85 years of age or more, and those $60-64$ years of age. This ratio shows a distinctly growing tendency. The growth from 1985 to 2020 will be from 16 percent to 30 percent.

The age structure is affected by the declining mortality which implies a longer life time but also declining fertility.

An attempt to assess the relative effects of mortality and fertility on the aging phenomenon has been made by Lutz (1987) by using a simple decompositional model, in which the changes in the ratio of women aged $60-79$ to those aged $0-19$ is applied as an indicator of population aging.

The ratio of women aged $60-79$ to women aged $0-19$ more than doubled over the 25 years from 1960 to 1985 . It is expected to increase more than four times its 1960 size by the year 2025 . In 1960 more than three young women aged $0-19$ existed per one elderly woman aged $60-79$, in 2025 there will be 30 percent more women aged $60-79$ than women aged $0-19$. When assuming constant mortality conditions the increase will be slightly less. Somewhat more than half of the aging is due to mortality improvements and less than half to declining fertility. The high importance of mortality relative to fertility is due to the model used: the ratios reflect mortality conditions back in the beginning of the century. For the very dramatic increase in population aging between 2000 and 2025 , however, only about one-third of the change may be attributed to mortality improvement and two-thirds to low fertility.

Although the aging of the population has gone on almost from the beginning of the century, it has not been very visible prior to the Second World War. From the 1950 s the proportion of aged people has increased continually.

One factor which contributed to the rapid growth of old age groups has been the growing birth cohorts at the end of the 19th century and at the beginning of this century. The number of births reached its maximum in 1909. The cohort born in 1909 was 65 years of age in 1974, which was also the year when the input into the population older than 60 years was at its peak. 
Since the 1970s aging has been remarkable. Increasing longevity has caused an augmentation of the oldest age groups. This is explicitly reflected in the ratio of those aged 75 or more to those 60 or more. This ratio has grown from 19 percent in 1970 to 28 percent in 1985 . It is true that the age structure has been older as a whole as a consequence of the sinking mortality but, so far, the difference is small compared with the situation in 1970. Now there are eight 60-64-year-olds to ten 40-44-yearolds. Compared with 1950 , for example, the situation has changed remarkably. In that year there were less than five 60-64-year-olds for every ten 40-44-year-olds (Table 3 ). The ratios show that the working-aged population has grown older and the proportion of older population increased rapidly.

The development toward a stationary population has been rather rapid in Finland. Still in the 1950 s the age pyramid had the classical triangular shape with a great proportion of children and young people (Figure 1). Truly, this profile was not so much affected by high mortality in young ages as was the case in earlier generations. The triangular form was to a great deal a result of the high postwar fertility. Gradually, when fertility decreased, the age profile became more rectangular, at least in younger age groups. Due to the expected small fertility and consequently less women in fertile age, the shape of the profile will be more narrow than that a stationary population implies.

A vision of the development toward a stationary Finnish population is given by an unpublished projection made by the Statistical Office. The projection assumes that total fertility will increase from the current 1.7 to 2.1 from 1985 to 2000 and then remain on this level. Mortality will go down. This means that the annual number of births will reach 66,000 around the year 2000 and continue on a level of $65,000-66,000$. The total population will increase from 4.92 million in 1985 to 5.26 million in 2020. After that it will again gradually decrease and will be 5.06 million in 2050. An almost stationary population will be reached already around 2020. An interesting and important feature is that the proportion of those aged 65 will be about 19 percent in the stationary population, or as large as those younger than 14 . The proportion of the population of working age, those aged $15-65$, will remain high, but will decrease from about 68 percent in 1985 to $60-61$ percent from 2020 on.

\section{The growing male predominance}

The sex ratio has changed significantly during the last centuries. While in the 18 th century the male-female ratio was almost one in all ages a gradual growth has occurred especially since the end of the 19th century. As a consequence of high mortality among boys still in the beginning of the 1900 s there were only 102 males per 100 females in the age group 10-19 (Table 4). The female preponderance was not visible prior to old age. The high mortality among women of working age kept the sex

Table 3. The $75+/ 60+$ and $60-64 / 40-44$ ratios in $1950-1985$.

$\begin{array}{ccc} & 60-64 / 40-44 & 75+/ 60+ \\ 1950 & 0.48 & 0.19 \\ 1960 & 0.69 & 0.20 \\ 1970 & 0.79 & 0.19 \\ 1985 & 0.80 & 0.28\end{array}$

Source: OFS VI A:106-151, 1952-1987. 
Table 4. Male-female ratio for ten-year age groups 1900-1985.

$\begin{array}{lrrrrrr}\text { Age groups } & 1900 & 1960^{1} & 1980^{1} & 1985^{1} & 2000 & 2020 \\ 10-19 & 101.6 & 104.1 & 104.2 & 104.3 & 104.4 & 104.5 \\ 20-29 & 101.1 & 102.3 & 105.3 & 104.8 & 104.0 & 104.0 \\ 30-39 & 99.4 & 94.3 & 105.7 & 105.8 & 102.9 & 102.9 \\ 40-49 & 96.8 & 85.3 & 100.9 & 102.4 & 102.3 & 101.0 \\ 50-59 & 90.8 & 83.6 & 87.2 & 93.1 & 100.1 & 97.2 \\ 60-69 & 84.8 & 70.5 & 67.0 & 70.6 & 88.4 & 92.1 \\ 70-79 & 75.6 & 56.4 & 55.2 & 54.7 & 65.6^{2} & 81.1^{2} \\ 80-89 & 60.2 & 48.1 & 39.0 & 37.6 & 39.9^{2} & 58.6^{2} \\ 90- & 42.8 & 45.5 & 30.3 & 27.6^{2} & 28.2^{2} & 39.9^{2} \\ \text { I Average population } & & & & & \\ 2 \\ \text { Social Insurance Institution 1990 }\end{array}$

Table 5. The projected number of men and women aged 85 or older in 1985-2020.

$\begin{array}{rrrrc} & \text { Men } & \text { Women } & \text { Total } & \text { Men/Women } \\ 1985 & 9530 & 30170 & 39700 & 0.32 \\ 1990 & 11920 & 39560 & 51480 & 0.30 \\ 2000 & 17090 & 57600 & 74690 & 0.30 \\ 2010 & 21250 & 67530 & 88780 & 0.31 \\ 2020 & 32250 & 67870 & 100110 & 0.48\end{array}$

Source: CSO Population 1989b, No. 3; The Social Insurance Institution 1990

ratio high in these age groups. During the following decades the sex ratio went down. After the Second World War the male-female ratio started to increase again gradually. The increase was especially marked in the younger age groups. In 1985 there were still more males in the age group 40-49.

Among the older population a decrease has been observed. While in the beginning of the century there were about six men per ten women in the population aged $80-89$ the proportion has gone down to about four per ten in 1985 . In spite of the fact that the sex ratios also are affected by wars and emigration, the trend is rather obvious. The excess mortality among men is visible in still higher ages, while the longevity of women has increased more rapidly than among men and the preponderance of women grows in the older ages.

After the turn of the century the ratio will ameliorate and in 2020 it will reach the same level as in the beginning of this century. Women will, however, still live longer than men even if the proportion of men among the oldest population, those aged 85 or more, will grow somewhat at the end of the projected period.

The tendency toward male predominance in young ages continues and reaches to still older ages. In the year 2000 there will still be more males than females in the ages 50-59. After that the excess mortality for men will increase and the male-female ratio will be about the same among the old population as it was in the 1980s. However, the projections show that the trend obviously will change in the beginning of the next century and the ratio will be more favorable for men. While the sex ratio among the 85-89-year olds in 1985 was 33, it will grow to 52 in 2020. Probably the sex ratio would have ameliorated earlier without the war in the 1940s. The worse ratio is to a great deal a consequence of war mortality and war injuries among men.

The proportion of the very old, those aged 85 or more, according to sex will change rather distinctly (Table 5). In 1985 there were 32 men older than 85 per 100 women in the same age category. In 2020 the proportion will have risen to 48 per 100 . 
Growing longevity lengthens matrimonial life or at least creates the possibility for a longer married life. The expected consequence is a decrease of the proportion of widows and widowers, especially among younger age groups. Further, if the longevity of males increases faster than that of females, the proportion of widows compared with that of widowers could be expected to decrease. On the other hand, the growing old age groups will lead to an increase in the number of widows and widowers. There are several trends which affect the development of the number and proportions of the widowed.

In 1980 there were almost three times as many newly widowed women as men. During the following decades the number of newly widowed will increase. According to the projection made by the Social Security Institution the number of widows' starting pensions, paid to all widows younger than 65 years during the first six months of widowhood, will show a downward tendency at the end of the 1980s. In the mid-1990s the pensions will increase and reach their peak in 2010, when about 20 percent more pensions will be paid than in 1985. After that they will go down again. The increase in the number of widows' starting pensions paid reflects the growth in the numbers of widows and widowers as a natural consequence of the aging of the population, with more individuals in old age.

An attempt to get an estimate of the number of widows and widowers in 2010 has been made by using the same mortality assumptions as used in the population projection made by the Central Statistical Office. It is further assumed that the frequency of being widowed and remarrying among widows and widowers will be the same as in the mid-1980s (properly speaking in 1985). Calculated in this way the number of widows in 2000 will be roughly one-fourth and in 201040 percent less than in 1985 . The number of widowers would, on the other hand, be 60 percent more than in 1985 (Table 6).

Among widows the decrease would be most accentuated in the youngest and the oldest age groups. Among widowers, again, the increase is most notable in the oldest age groups. The proportional distribution of widows and widowers would shift significantly from 1985 to 2010 to older age groups (Figure 2).

The decrease in the number of widows seems to be mainly a consequence of the earlier higher propensity to become a widow when the life expectancy of males was

Table 6. Number of widowed persons in 1985, 2000 and 2010.

\begin{tabular}{|c|c|c|c|}
\hline \multicolumn{4}{|c|}{ Widows } \\
\hline Age & 1985 & 2000 & 2010 \\
\hline-49 & 14451 & 5500 & 3300 \\
\hline $50-64$ & 64520 & 30400 & 25500 \\
\hline $65-74$ & 94861 & 54100 & 40200 \\
\hline $75-100$ & 109344 & 112100 & 96000 \\
\hline Total & 283176 & 202100 & 165000 \\
\hline & 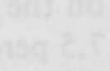 & & \\
\hline-49 & 2672 & 3200 & 2600 \\
\hline $50-64$ & 10430 & 16000 & 19200 \\
\hline $65-74$ & 14868 & 22200 & 25400 \\
\hline $75-100$ & 22177 & 37700 & 46600 \\
\hline Total & $50 \quad 147$ & 79100 & 93800 \\
\hline
\end{tabular}

Source: OSF VI A:151, Vol. 1, 1987. 
Figure 2. The proportional distribution of widows and widowers in 1985 and 2010.

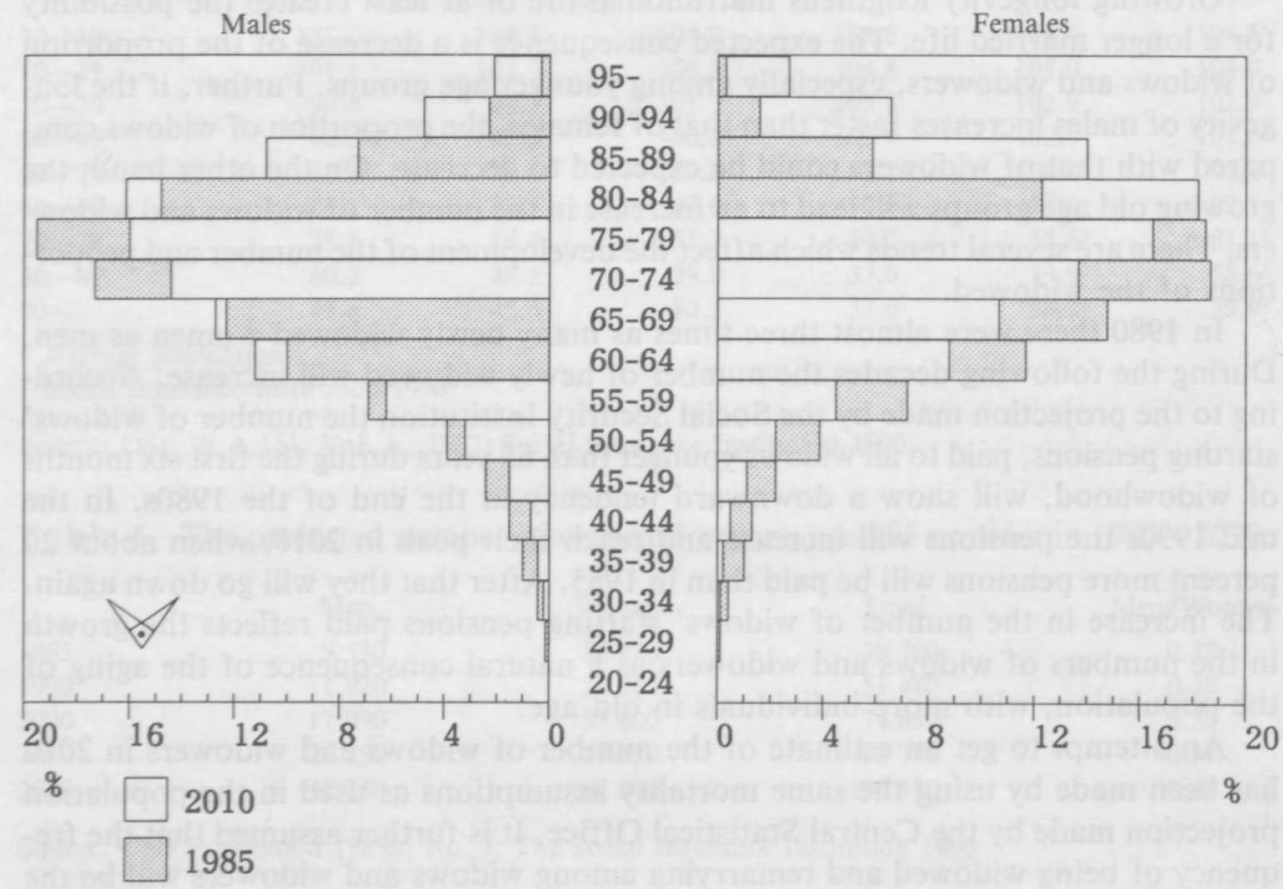

Source: OSF VI A 151, Vol. 1, 1987

lower. When the yearly number of new widows is lower than the yearly mortality among widows, the total number will decrease. Already in 1985 the number of deaths among widows was 20 percent greater than the number of new widows. The increase in the number of widowers is mainly a consequence of growing longevity among men and the changing age distribution. In 2010 there will be 54 percent more men older than 50 years than in 1985 , but only 31 percent more women. Hence, the increase of newly widowed men and women is closely connected to population development. However, the calculation used might include a tendency to give somewhat too great a number of widows, as it does not take into consideration the somewhat more rapid growth of longevity of men than of women. ${ }^{2}$ Even so, the difference between the life expectancy of males and females is rather small.

\section{The unpredictable labor force market}

Since the 1970s, unemployment has put its imprint on the labor force market. Having been at a level of $2-3$ percent, it rose in 1978 to 7.5 percent. After this peak it went down again, but still during last few years it has been 4-5 percent, somewhat higher among men than among women. However, simultaneously with unem-

2 The calculation is made by using the simulation program DIALOG created at IIASA in Vienna. 
ployment there has been a growing shortage of labor force in the most industrialized, southern part of the country, especially of skilled workers in the manufacturing industry. One reason often mentioned is that manufacturing work does not attract young people anymore.

However, the present unemployment rate is to a great deal a consequence of the rapid structural changes in Finland. The vocational and educational structure of the unemployed and of job seekers no longer correspond with the labor force demand.

Until now the labor force (employed and unemployed aged 15-74) has grown continuously, from 1970 to 1988 by 18 percent.

During the same time, the economically active population has gone down from 61 percent to 57 percent of the total population (Table 7). The decrease is especially marked in the youngest age group, 15-24 years of age. In 197055 percent of this age group was economically active, in 1985 only 41 percent. A great difference is visible between the sexes. While the economical activity among males has decreased from 74 percent to 63 percent during these fifteen years, it has been almost unchanged among females, or 48.8 percent in 1970 and 51.8 in 1985 . Another salient feature is the shrinking economical activity among those older than 65 years. In 19707.4 percent of those who had reached the common age of retirement were working. In 1985 only 1.8 percent were economically active.

Among the young age groups economic activity has decreased during the last decades as a consequence of longer education, which sometimes seems to be an artificial prolongation caused by the present financial aid system to students; students are e.g. tempted to prolong commencing repayment of their student loans. However, it is likely that the shortage of young people in the future will force enterprises to take in students with only a basic education and even those without any occupational education. The vocational training will be given by the enterprise itself. This will increase the economic activity of the young age groups. On the other hand, there seem to be tendencies working in the opposite direction. The small cohorts born in the 1960 s or later, the "computer generation», seem to insist on greater autonomy. The impact of this is perhaps a trend towards lower economical activity e.g. in the shape of sabbatical years of different length.

One of the greatest changes in the labor force structure is the growing proportion of female workers.

The increase has been rapid especially in the most active age groups of women. In the 1960 s the proportions were about $60-70$ percent, but in 1986 around 90 percent (Figure 3).

Table 7. Economically active population in 1970 and 1985 , percentage of the total population.

$\begin{array}{lcccccc}\text { Age } & \begin{array}{c}1970 \\ \text { Both } \\ \text { sexes }\end{array} & \text { Males } & \text { Females } & \begin{array}{r}\text { Both } \\ \text { sexes }\end{array} & \text { Males } & \text { Females } \\ 15-24 & 55.0 & 61.2 & 48.5 & 40.7 & 41.1 & 40.3 \\ 25-34 & 81.0 & 94.2 & 67.4 & 83.0 & 87.7 & 78.1 \\ 35-44 & 81.9 & 95.9 & 67.9 & 85.3 & 88.7 & 81.8 \\ 45-54 & 74.5 & 89.7 & 61.7 & 78.8 & 80.4 & 77.1 \\ 55-64 & 53.3 & 71.1 & 39.5 & 40.1 & 42.7 & 40.0 \\ 65- & 7.4 & 13.8 & 3.6 & 1.8 & 3.1 & 1.1 \\ \text { Total } & 60.9 & 74.3 & 48.8 & 56.9 & 62.5 & 51.8\end{array}$

Source: OSF VI C 107 Vol. 1, Table 2, Table I: 26, 1988; OSF VI A:132, 1973; OSF VI A:151, Vol. 1, 1987. 
Figure 3. Female labor force participation rate 1986, by age.

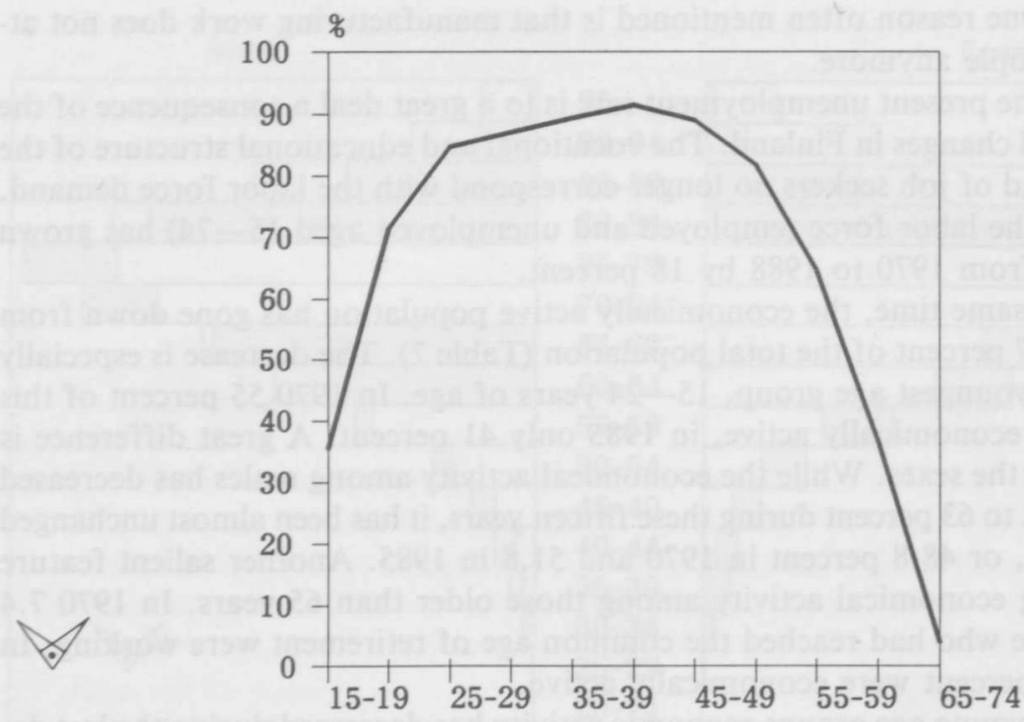

Source: Työvoimakatsaus, No. 2, 1987, p. 24

Since the mid-1980s the supply of labor force has shown a shrinking tendency and at the end of the century the output will be greater than the input. While the labor force grew by 124,000 persons from 1980 to 1985 , the projection made by the Ministry of Labor states that the growth will be only 38,000 persons during the whole 1990s (Työvoimaministeriö 1988). Nevertheless, the supply of labor force will, according to the Ministry, be large enough to satisfy the demand. The problems will arise later, in the beginning of the next century. In the beginning of the following century the labor force will start to decrease. When using the same labor force participating rates by sexes as used by the Ministry of Labor in the projection of demand and supply of labor force (1988) for the year 2000, the labor force would diminish by two percent from 2000 to 2005 and by 3.5 percent from 2005 to 2010 (Table $8)$. At the same time the total participation rate would get smaller. The participation rate of the population aged 15-64 would decrease from 76 percent in 2000 to 73 percent in 2010. This is a direct consequence of population aging; the older age groups with low labor force participating rates are growing. Even the youngest age groups will decrease somewhat but their participating rate is rather low, and consequently the effect on the participating rate small.

On the other hand, commerce and industry calculate that with a moderate economic growth after 1995, Finland will need 10,000-15,000 foreign workers per year (Pirttimäki 1990).

According to the population projection made by the Statistical Office the number of 55-64-year-olds, the age group representing the output from the labor force, will be larger than the age group from which the main input to the labor force occurs, i.e. the 20-29-year-olds, just after the turn of the century (Figure 4).

In reality, however, the situation is much more complicated. Although the retiring age in most fields is 65 years, there are numerous occupations where it is lower. In the oldest age groups (55-64 years), a large part are pensioners because of in- 
validism or unemployment. In 198813.2 percent of this age group were on unemployment pension and 28.5 on invalid pension. In addition, various early retirement pension systems provide an opportunity to retire earlier than the ordinary retiring age, with a somewhat smaller pension than the ordinary old age pension. Altogether 57 percent of this age group were pensioners in 1988 (Hytti et al. 1990, 3).

The proportion of the economically inactive population is, of course, much larger. In Table 9, which shows the growth trend of the economically inactive population, it is assumed, lacking better forecast alternatives, that the proportion of students will be the same as in the beginning of the $1980 \mathrm{~s}$. The number of the disabled is based on a calculation made by the Social Insurance Institution (1989). Further, it is assumed that the number of retired persons younger than 65 years would grow as rapidly as the number of the disabled. However, during the 1980 s the retired youn-

Table 8. Labor force in 2000,2005 and 2010 (1,000 persons), if the labor force participating rate is the same as used in the labor force projection made by the Ministry of Labor for the year 2000 .

$\begin{array}{lrrrrr} & 2000 & & 2005 & & 2010 \\ & \text { Total } & \text { Total } & +- & \text { Total } & +- \\ 15-24 & 315 & 306 & -9 & 288 & -18 \\ 55-64 & 270 & 348 & +78 & 353 & +5 \\ \begin{array}{l}\text { Labor force } \\ \text { participation }\end{array} & 2,580 & 2,527 & -53 & 2,438 & -89 \\ \text { rate } & & & & & \\ & 78.8 & 74.2 & & 72.7 & \end{array}$

Source: Työvoimaministeriö 1988, CSO 1989.

Figure 4. The number of 20-29- and 55-64-year-olds in 1980-2005.

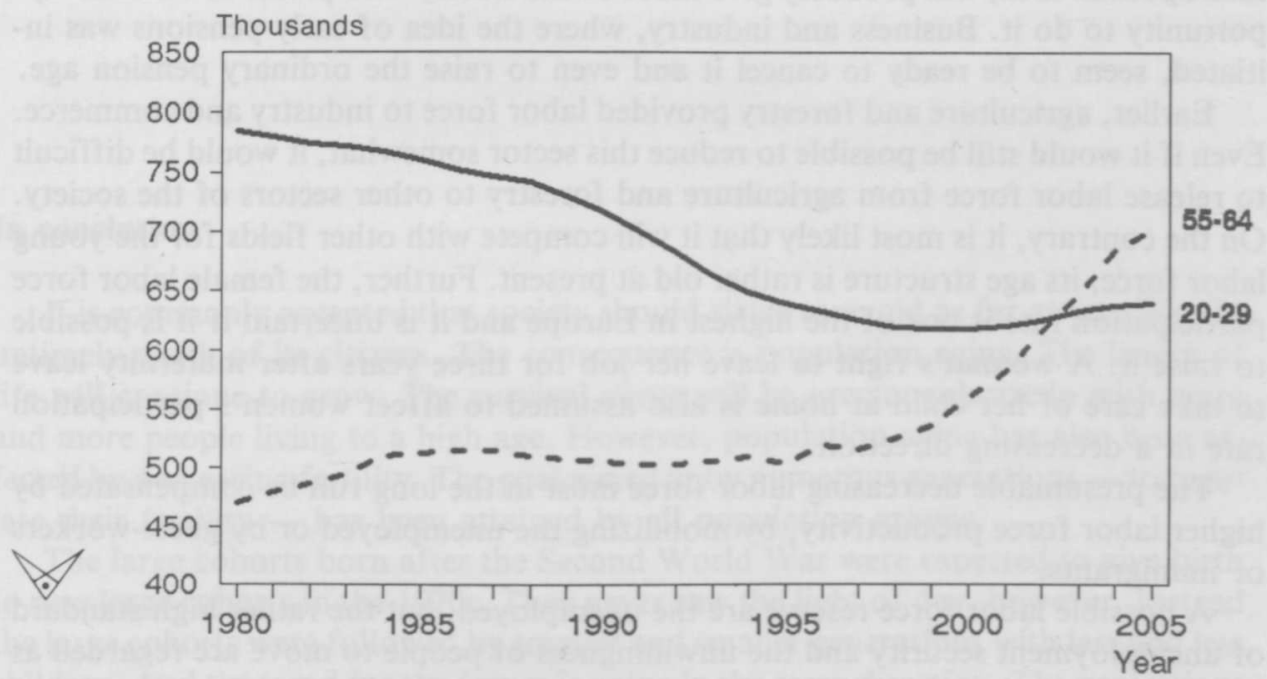

Source: OSF VI A:145-153, 1980-1988; The Social Insurance Institution 1986; CSO VÄ 1985:10; Unpublished data from the Central Statistical Office of Finland. 
Table 9. The economically inactive population, 1987-2010.

\begin{tabular}{|c|c|c|c|c|c|c|}
\hline & 1987 & $\%$ & 2000 & $\%$ & 2010 & $\%$ \\
\hline 0 -14-years old & 952,900 & 40.4 & 868,800 & 35.6 & 792,200 & 31.5 \\
\hline Students aged $15-29$ & 356,500 & 15.1 & 316,000 & 13.0 & 305,900 & 12.2 \\
\hline $\begin{array}{l}\text { Retired younger } \\
\text { than } 65 \text { years }\end{array}$ & 407,200 & 17.3 & 492,700 & 20.2 & 586,000 & 23.3 \\
\hline $\begin{array}{l}\text { Retired older } \\
\text { than } 65 \text { years }\end{array}$ & 639,300 & 27.1 & 760,100 & 31.2 & 832,700 & 33.1 \\
\hline Total & $2,355,900$ & 99.9 & $2,437,600$ & 99.9 & $2,516,800$ & 100.1 \\
\hline $\begin{array}{l}\text { Proportion of the } \\
\text { whole population (\%) }\end{array}$ & 47.7 & & 48.6 & & 50.5 & \\
\hline
\end{tabular}

Source: The Social Insurance Institution 1989. (Unpublished calculation).

ger than 65 years have increased much faster than the disabled. Hence, if the rate of growth is the same during the following decades as in the $1980 \mathrm{~s}$, the increase will be greater than in the assumption used here. On the whole, the proportion of the economically inactive population will grow from 47.7 percent in 1987 to 50.5 percent in 2010.

The early retirement introduced a couple of years ago has been highly popular. There are several reasons for its success. The main one is said to be having had enough of one's job. For many older employees early retirement seems to be the safest alternative, especially when during the reorganization of enterprises, caused by the structural changes in the society, the threat of being fired is primarily directed toward the elderly employees. Also the progression of taxation, the opportunity to use several forms of free service contribute to this, all of which make the transition to lower income from pension easier. (EVA 1989).

Surveys show that people do not value work as earlier, they prefer to retire as soon as it is possible. Of course, in addition, pensions are better than ever. Most probably the trend toward early retirement will continue in the 1990s. On the other hand, the predicted scarcity of labor force, which already has been noticeable in the metropolitan area, will probably give those of the elderly who prefer to work an opportunity to do it. Business and industry, where the idea of early pensions was initiated, seem to be ready to cancel it and even to raise the ordinary pension age.

Earlier, agriculture and forestry provided labor force to industry and commerce. Even if it would still be possible to reduce this sector somewhat, it would be difficult to release labor force from agriculture and forestry to other sectors of the society. On the contrary, it is most likely that it will compete with other fields for the young labor force; its age structure is rather old at present. Further, the female labor force participation rate is one of the highest in Europe and it is uncertain if it is possible to raise it. A woman's right to leave her job for three years after maternity leave to take care of her child at home is also assumed to affect women's participation rate in a decreasing direction.

The presumable decreasing labor force must in the long run be compensated by higher labor force productivity, by mobilizing the unemployed or by guest-workers or immigrants.

A possible labor force reserve are the unemployed, but the rather high standard of unemployment security and the unwillingness of people to move are regarded as important obstacles to mobilizing the unemployed. The female labor force has shown an increase during the last decades. It is, however, not very probable that the in- 
crease will continue because the labor force participation of women already is very high and hence considered to have reached its peak.

There is, however, confidence in the possibility of keeping the old age groups in the labor force, to postpone retirement more or less until the normal age of retirement and probably raise the upper age of retirement. This often calls for retraining these age groups. Those who in the 1990 s will choose early retirement belong to the large age groups born after the Second World War and a great part of them have received a rather poor basic education. However, most people seem to think that the vocational training they have got in their youth is enough for their whole lifetime. Structural changes might liberate some labor force but transferring from one occupation to another is difficult: retraining is not favored, even less changing one's occupation or trade. In order to persuade old workers to return to the labor market, incitements other than free re-education alone obviously have to be introduced, e.g. tax reliefs or a more advantageous part-time work system.

At present there are very few foreign guest-workers in Finland, only a few thousand. Compensating for the shortage of labor force in the future with foreign workers has to be seen from several angles. On the whole, Finns are rather unacquainted with communicating with persons from other cultures and have a sceptical attitude toward foreigners. An atmosphere like that is not very attractive to immigrants. Further, the winter is long, cold and dark. However, it is not known if it would be possible in the future to have people come from the Baltic countries or Soviet Carelia, which are culturally close to Finland. Nevertheless, experts seem to be convinced that we must be prepared for a more large-scale migration in the future including inmigration of guest-workers and refugees as well as out-migration of the highly educated to integrating Europe.

For a long time the proportion of the working age population will be as high as it has been in the 1980 s, or two-thirds of the whole population. The working age population will begin to diminish around the 2020 s, or after the period examined in this study. On an international level, the labor force participation rate in Finland is rather high at present. Evidently, growing prosperity, better social security and pensions will continue to reduce the central position of working, will make sabbatical years and early retirement more common, and will diminish the labor participation rate.

\section{In conclusion}

It is commonly accepted that society should strive to avoid as far as possible the untimely death of its citizens. The consequence is population aging. The length of life will continue to grow. The survival curve will be »rectangularized» with more and more people living to a high age. However, population aging has also been affected by decreasing fertility. The goal aimed at by numerous generations - to regulate their fertility - has been attained by all population groups.

The large cohorts born after the Second World War were expected to give birth to new large cohorts in the 1970s. They never saw the light of day, however. Instead the large cohorts were followed by smaller and smaller generations with less and less children. And the trend for the future is going in the same direction. The projections show that the number of children will be less in the future, not so much as a result 
of decreasing fertility than as a consequence of a shrinking fertile age group. It does not seem likely that there will be a stable fertility increase in the reasonable near future, even if there might be some ups and downs in the fertility curves in the future.

Recent trends in mortality suggest that life expectancy will grow during the following decades. Even if longevity increases, the difference between men and women seems to remain. The great changes in age structure which until now have been rather small will occur in the next century. Especially the proportion of old people will continue to grow during the first decades of the 2000 s.

A direct consequence of population aging is decreasing labor force participating rates in the beginning of the new century. The older age groups with low labor force participating rates are growing. Even the youngest age groups will decrease somewhat, but their participating rates are low, and therefore their effect on labor force consequently small.

The trend towards an aging population seems to be unavoidable and irrevocable. To retain a young population structure does not seem to be feasible, as it implies continuously growing fertility, and consequently, also a growing population.

The effects of population aging will probably be most noticeable and painful in small municipalities, when the population becomes too small for the community to function. Other consequences are a changing female-male ratio and increasing shortage of manpower.

The demographic trends unavoidably lead to population aging. The coming shortage of labor force will obviously make it necessary to open the borders to guestworkers or immigrants. Fortunately, the development towards an aging society is slow, which makes it possible to make projections and plans for the future in order to avoid unwanted consequences and mistakes.

\section{References}

CSO (1985). VÄ 1985:10. Population Projection by Municipalities 1984-2010. Helsinki: Central Statistical Office of Finland.

CSO (1989a). Statistical Yearbook of Finland 1989. Helsinki: Central Statistical Office of Finland.

CSO (1989b). Population 1989:3. Population projection by municipalities 1988-2010. Helsinki: Central Statistical Office of Finland.

EVA (Elinkeinoelämän valtuuskunta) (1989). Työtä tarjolla! missä tekijät? (Jobs in supply! where are the workers?). Helsinki: Elinkeinoelämän Valtuuskunta.

Hytti, Helka et al (1990). Varhaiseläkkeet 1980-luvulla (Early retirement pensions in the 1980s). Unpublished paper.

Lutz, Wolfgang (1987). Effects of fertility trends on population aging in Finland. Yearbook of Population Research in Finland 25: 19-29.

OECD (1990). OECD in figures. Statistical supplement to the OECD Observer No. 164, June/July. Paris: Organisation for Economic Co-operation and Development.

OSF (Official Statistics of Finland). (1986). XL:11. Labour Force Survey 1985. Helsinki: Central Statistical Office of Finland.

OSF (Official Statistics of Finland). (1988). VI C:107. Population Census 1985. Volume 1. Economic activity of population. Helsinki: Central Statistical Office of Finland.

OSF (Official Statistics of Finland) (1952-1988). VI A:106-153. Vital statistics 1950-1986. Helsinki: Central Statistical Office of Finland.

Pirttimäki, Paavo (1990). Väestönkehitys ja elinkeinoelämä (Population trends and economic life). In: Suomalainen väestöruletti - viisi näkökulmaa Suomen väestön tulevaisuuteen, Kolmikantasarja No. 12, pp. 110-140 Helsinki: Väestöliitto. 
The Social Insurance Institution (1986). 1. Väestöennuste; 2. eläkkeensaajien lukumääriä koskevat ennusteet (1. Population projection; 2. projected number of pension beneficiaries 1985-2050). Kansaneläkelaitoksen julkaisuja T9: 27. Helsinki: Kansaneläkelaitos.

The Social Insurance Institution (1990). Population projection 1989-2050. Kansaneläkelaitoksen julkaisuja T9: 37. Helsinki.

Työvoimaministeriö. Suunnitteluosasto (1988). Työmarkkinoiden tulevaisuus: työvoiman kysyntä vuoteen 1995 ja tarjonta vuoteen 2000 (Future of the labor market: demand for labor until 1995 and supply until 2000). Työvoimapoliittisia tutkimuksia, No. 73. Helsinki. 